\title{
Causality between Economic Growth, Export, and External Debt Servicing: The Case of Lebanon
}

\author{
Wadad Saad \\ Correspondence: Wadad Saad, Faculty of Economics and Business Administration, Department of Economics, \\ Lebanese University, Branch 1, Hadath, Lebanon. Tel: 961-3-880036. E-mail: wsaad@ul.edu.lb
}

Received: August 31, 2012

Accepted: September 17, 2012

Online Published: October 11, 2012

doi:10.5539/ijef.v4n11p134

URL: http://dx.doi.org/10.5539/ijef.v4n11p134

\begin{abstract}
The econometric relationship between external public debt, exports and economic growth in Lebanon has been rarely examined. This study empirically investigates the relationship between economic growth, exports and external debt of Lebanon through an econometric analysis over the period 1970-2010 with the inclusion of a fourth macroeconomic variable that is the exchange rate. The exports were introduced in the model to test the export-led growth hypothesis for Lebanon. We explore this relationship using the vector error correction models (VECM) and we employ Granger causality technique in order to investigate the presence of causality among these variables. The results show that both short run and long run relationships exist among these variables. Moreover, the finding suggests, $i$ ) bidirectional Granger causality between GDP and external debt servicing, $i$ ) unidirectional Granger causality that runs from external debt to exports, iii) unidirectional causality running from exports to economic growth, and $i v$ ) unidirectional causality running from exchange rate to economic growth.
\end{abstract}

Keywords: economic growth, exports, external debt, cointegration analysis, causality

\section{Introduction}

The relationship between economic growth and exports in developing countries has drawn the attention of researchers theoretically and empirically. A host of empirical studies have been conducted to investigate the role of exports on economic growth or the export-led growth hypothesis. This latter stipulates that export is an engine to promote economic growth and hence increases the rewards of factors of production. Moreover, it opens opportunities for investments in the economies as a result of the higher level of income and saving, which leads in return to sectoral growth. The importance of export and its impact on economic growth raises the question about the nature of the relationship between these two macroeconomic variables. In other words, it is useful to investigate whether the co-movement between exports and GDP is in line with the export-led hypothesis or whether a causal relationship exists between the two variables.

Bivariate causality analysis leaves out some other relevant variables such as external debt, exchange rate, inflation, external debt servicing, etc. that could have significant relationship with the two variables in question. For that reason we find many empirical studies that improved the export-led growth strategy by including in their models one or more relevant macroeconomic variables. For instance, Sheehey (1990), Jones (1989) provided studies which test the causal relationship among economic growth, exports and external debt servicing. Others introduced different variables such as imports (Din, 2004), world income (Afzal, 2006), and external debt (Amoateng and Adu, 1996), etc.

Bivariate causality studies provided conflicting empirical results. This situation may be due to the misspecification of the causal model used in these studies because of the omission of an important third variable such as foreign debt, among others. Therefore, the omission of external debt servicing variable, for instance, could seriously bias the empirical causality results between export and economic growth in the case of Lebanon since foreign debt servicing is a major disbursement item.

The economic situation in Lebanon has undergone many difficulties due to several economic and political events which unexpectedly have been occurring at internal and external levels since 1975.

Lebanon's external and internal debts are seen to be the cause of the major problems that causes troubles to the economy since 1993. Moreover, in all fiscal years since 1964, the government's revenue has been less than its expenditure, which causes fiscal deficits that are covered by borrowing from both internal and external sources. 
External debt may have a positive or a negative impact on economic growth depending on its uses. It could affect the economy positively when the government uses it for investment-oriented projects such as infrastructure, power, and the agriculture sector. However, it could have a negative impact when it is employed for private and public consumption. In general a lower level of the external debt affects positively the economic growth. This impact becomes negative at a higher level. The specific turning points are $35-40 \%$ of the debt-gross domestic product (GDP) ratio and $160-170 \%$ of the export-debt ratio (Note 1). The lower is the first ratio (the higher the second ratio) the better is the impact on economic growth.

In Lebanon, the external debt was at low levels till 1992. The external debt-GDP ratio started to grow steadily from 5.7\% in 1993 to reach $90.6 \%$ in 2007 and then declined to $52 \%$ in 2010 . As to export-external debt ratio, it was very high before 1986. It started to decrease from $339 \%$ in 1986 to arrive at its lower level $20.8 \%$ in 2002 and then increased to $40.8 \%$ in 2010 (see table 1).

Table 1. External debt as percentage of GDP and export as percentage of external debt

\begin{tabular}{lcccccccc}
\hline Year & 1986 & 1987 & 1992 & 1993 & 2002 & 2006 & 2007 & 2010 \\
\hline External debt-GDP ratio & 7.7 & 26.6 & 4.7 & 5.7 & 77.9 & 90.6 & 84.7 & 52 \\
Export-external debt ratio & 339 & 153 & 186 & 150 & 20.8 & 23.4 & 27.2 & 40.8 \\
\hline
\end{tabular}

In light of the above discussion, the objective of this study is to investigate the impact of exports in shaping the economic growth in the case of Lebanon with the inclusion of two economic variables that are external debt servicing and exchange rate. A cointegration analysis based on Johansen procedure is used for this purpose. Moreover, the causality between these variables is explored using Granger causality test. The data used in this study cover the period from 1970 to 2010 .

The study is organized as follows, in section II, we analyze the economic situation in Lebanon. Section III presents the literature review of causality relations among GDP, export, and other macroeconomic variables in a country or a group of countries. Section IV explains the methodology used in this research. Section V presents the data and variable description. In section VI, we present the obtained results regarding the cointegration analysis and the Granger causality tests. The last section concludes the main findings.

\section{The Economy of Lebanon: A Background}

This study attempts to establish the relationship between economic growth, export, exchange rate, and foreign debt servicing in Lebanon during the period from 1970 to 2010. The main objective of this research is to examine the effect between these four macroeconomic variables and the specific aim is to identify the causality between them.

\subsection{The Lebanese GDP}

The economic situation in Lebanon has undergone many difficulties due to several economic and political events which unexpectedly have been occurring at internal and external levels since 1975. The Lebanese economy performed well in the era of 1990 to 2010 in which economic growth was growing at an average rate of 7 percent annually (see fig. 1). However, the period between 1975 and 1990 witnessed a lot of fluctuations due the civil war that took place during that time.

After 1992 the country witnessed a period of economic recovery that is characterized by security stability in most regions of Lebanon (except for the areas under occupation and some major political events in 1996, 2005, and 2006) and strong local currency. The government started to apply a wide rehabilitation policy based on the rebuilding of the infrastructure and the launching of new projects in order to enhance the economy. However, the expenditures exceeded significantly the revenues, forcing the government to seek for domestic and external borrowing in order to finance the public deficits. 


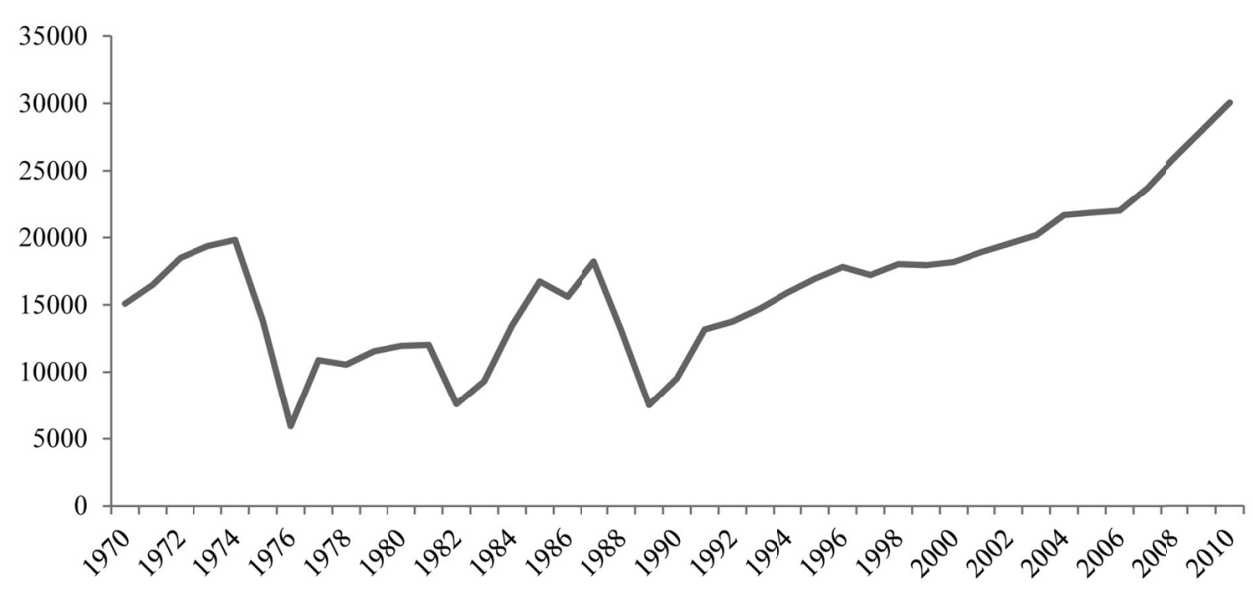

Figure 1. Real GDP in Lebanon (in millions of US\$) from 1970 to 2010

Source: United Nations Statistics.

The country has been exposed to slowing economic growth since mid-1995 as a result of inappropriate regional atmosphere, not investing in productive projects, the escalation of debt service remarkably, and finally the widespread of the corruption in the public administrations and institutions.

\subsection{The Lebanese Exports}

The exports in Lebanon witnessed significant developments in the period before 1975 which was the start date of the Lebanese civil war. The value of exports grew from 351 million dollars in 1970 to reach 2214 million dollars in 1975. The reason for that lies in the fact that the structure of the Lebanese exports does not depend on the export of one commodity as is the case in most developing countries. For instance, more than $90 \%$ of the exports of the Gulf countries are based on oil. However, the export performance of Lebanon was exposed to a period of fluctuations during the civil war that took place from 1975 to 1990 (see fig. 2). Lebanese exports were dramatically affected by the Lebanese events and it was noticed that whenever the security situation improved, the better the exports were. In 1976 exports dropped to a lower level to reach about 300 million dollars, which was a decline of about $86 \%$ compared to 1975 . Afterward, the value of exports knew periods of ups and downs till 1992. The decline in some periods was the result of partial or total destruction of national production companies and the disabling of the port of Beirut, which was the main artery for the import of raw materials and equipment necessary for the production processes. This port was also the main gate to export Lebanese product abroad. However, in the period between 1993 and 2010 exports grew steadily at an average rate of $13 \%$ annually. It is important to mention that the main importers of the Lebanese production are Arab countries.



Figure 2. Exports of goods and services in Lebanon from 1975 to 2010. (Current US\$)

Source: United Nations Statistics. 


\subsection{Lebanon's Foreign Debt}

Before 1975, the level of foreign debt was minimal. From 1976, following the break out of civil war in 1975, which exerted remarkable pressure on government finances, it became necessary to borrow for balance of payments support and project financing.

Till 1975 the ratio of public debt to GDP was very low but soon this debt was accumulated very quickly with the continuation of Lebanese events and the escalation of its intensity and duration to rise from about $\$ 67$ million dollars in 1975 to about $\$ 4$ billion in 1982, only 6\% of this latter was attributed to external debt.

The debt was accumulated due to the decline in revenues and the growing expenses imposed by the events and the indulgence of governments in public spending. However, the continued confidence in the state and the influx of capital on Lebanon limited the deterioration of the exchange rate of pound (3.8 pounds to one dollar in 1982 compared to 2.5 pounds in 1975).

Figure (3) indicates that Lebanon's external debt remained at very low levels till 1992. Afterward, external debt increased from $\$ 429$ million in 1993 to $\$ 21.221$ billion in 2007 and then declined to $\$ 20.590$ billion by 2010 .

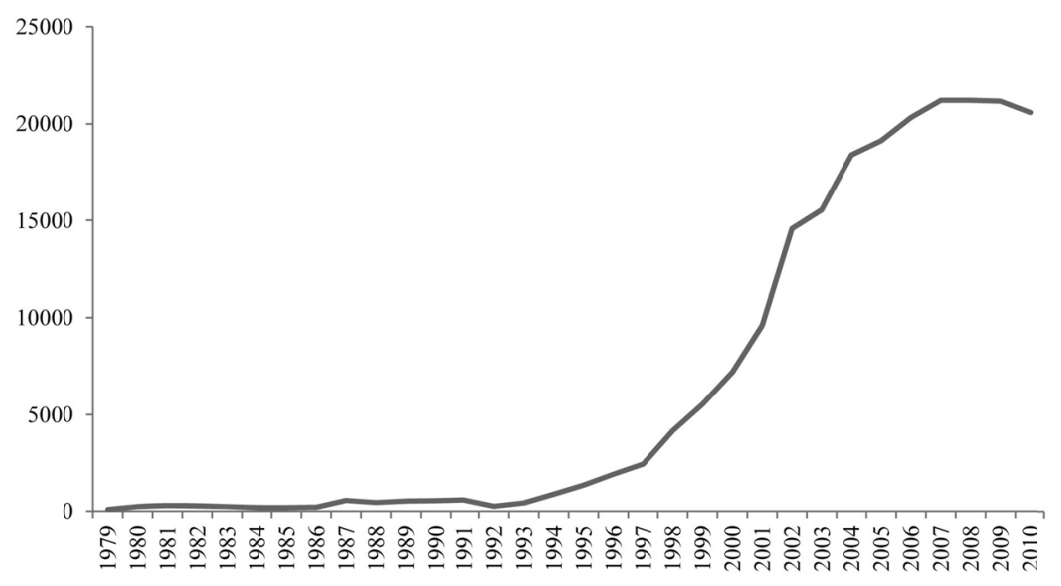

Figure 3. Lebanon's external debt from 1975 to 2010. (Current US\$)

Source: United Nations Statistics.

External debt constituted $4.7 \%$ of the gross domestic product in 1992. However, this ratio rose considerably to its highest level $90.6 \%$ in 2006 , but it started to decline since that date to reach $52 \%$ in 2010 (see table 2).

Table 2. Total debt as percentage of GDP and external debt as percentage of GDP and total debt

\begin{tabular}{lcccccccc}
\hline Year & 1979 & 1987 & 1992 & 1993 & 2002 & 2006 & 2007 & 2010 \\
\hline Total debt as percentage of GDP & 23.5 & 19.2 & 50.7 & 13.4 & 167.7 & 179.9 & 167.2 & 134 \\
External debt as percentage of GDP & 2.7 & 26.6 & 4.7 & 5.7 & 77.9 & 90.6 & 84.7 & 52 \\
External debt as percentage of total debt & 11.3 & 13.9 & 11.2 & 13.4 & 46.5 & 50.3 & 50.48 & 39.1 \\
\hline
\end{tabular}

The accumulation of this debt was the result of financing the rehabilitation projects for boosting the economy after the end of the Lebanese civil war in 1990. But the subsequent period has seen a lot of leniency in spending as well as the expansion in employment and the establishment of several futile institutions. As you notice in table (2) the total public debt increased tremendously since 1992 and constituted $179.9 \%$ of the GDP in 2006 . This ratio slightly declined to $134 \%$ in 2010 .

\subsection{Exchange Rate}

The exchange rate of the Lebanese currency witnessed great stability until 1980. During that period exchange rate maintained a very narrow margin for exchange rate of the dollar ranged between 3.43 and 22.3 pounds. This 
matter continued till 1980, and then the exchange rate of foreign currencies jumped in a way that it hadn't seen before. The exchange rate of the dollar doubled in 1982 to become about 4.72 after it was about 2.33 in 1974 . After that it tripled in the year 1984 and became 176 times more in 1988 and about 378 more in the year 1990 compared to what it was in 1974. As a result, the Lebanese pound lost the confidence of depositors and people refrained from its acquisition. Moreover, prices of goods and services increased dramatically and hence, the economy suffered from a huge phenomenon of inflation. This situation was aggravated after the 1990 Gulf War and the Lebanese pound deteriorated more and more to reach 605 Lebanese pounds for every dollar exchange rate in 1990 and 1750 in 1992. But it started to have some improvements and stability since that date due to the government adoption of a fixed exchange rate.

\section{Literature Review}

A host of empirical studies have attempted to investigate whether exports and economic growth are correlated and determine the direction of this causation. The empirical analysis, based on the export-led economic growth hypothesis, has provided mixed results in a bivariate causality analysis. In most studies, this latter was investigated using Granger causality. In addition, the long and short run equations were estimated using vector autoregressive models. For instance, there are Awokuse (2005) who examined this relationship for Korea, Lee and Pan (2000) who investigated this link for eight East Asian countries. Moreover, Mah (2005) found bidirectional causality in China. Similarly, Hatemi (2002) examined the bi-directional causal relationship in Japan. Demirhan and Akcay (2005) found that exports cause economic growth in Morocco and Jordan.

Some studies also used causality analysis at trivariate level between exports, economic growth, and a third relevant macroeconomic variable such as imports, external debt, external debt servicing, income, etc. For instance, Eita and Jordaan (2007) supported the export-led growth hypothesis in Namibia by finding that export Granger causes GDP and per capita income. Baharumshah and Rashid (1999) investigated long run causal relationship between exports, GDP, and imports of Malaysian economy. Similarly Khalid and Cheng (1997) also found long-run relationship among the three variables. Shirazi and Manap (2004) found strong long-run relationship among the three variables. Moreover, Ahmed et al (2000) examined the trivariate causality between export, external debt and economic growth for South and South-East Asian countries and reached the result that there is no joint feedback among them. Moreover, Amoateng and Amoako-adu (1996) examined the causality relationship among exports, external debt and economic growth in African countries, their results indicated bidirectional causality between external debt, economic growth and exports. Awokuse (2007) studied the impact of export and import on economic growth in three transition economies and found a bidirectional causal relationship between exports and growth in Bulgaria and causality from import and export to economic growth in the Czech Republic and only a unidirectional causality between import and growth in Poland. Tang and Lai (2011) investigated the validity of export-led growth hypothesis for Asia's four little dragons by using bivariate (exports and GDP) and trivariate (exports, GDP, and exchange rate) models. Their results showed that growth led export hypothesis is valid only for the case of Hong Kong and Singapore in the bivariate model but valid for all four economies in the trivariate model. Cetintas and Barisik (2009) analyzed the relationship between export, import and economic growth for the 13 transition economies by using a panel vector error correction model. Their results indicated that the export-led growth hypothesis is supported in those countries. However, some studies found no causal relationship among the variables in question such as Ribeiro (2001) in Portugal economy and Hsiao (1987) in four Asian economies.

\section{Methodology}

This study uses cointegration analysis and error-correction models to explore the relationship among the GDP, exports, exchange rate, and external debt serviving. Moreover the causality between each pair of variables is investigated using Granger causality.

In fact, most of the economic series are non-stationary at their levels. The use of such series in regression analyses lead to spurious regression (Granger and Newbold, 1974). For this reason, to explore the order of integration of the series in question we will use two tests: Augmented Dickey-Fuller test (1979) test and Phillips-Perron test (1988) test. The ADF test is employed using the ordinary least square (OLS) estimation of model (1):

$$
\Delta y_{t}=a_{0}+a_{1} y_{t-1}+\sum_{i=1}^{p} \emptyset_{i} \Delta y_{t-i}+u_{t}
$$


where $y_{t}$ is the time series, $\Delta$ is the first difference operator, $u_{t}$ is the error term with zero mean and constant variance, and $a_{0}, a_{1}, \emptyset_{i}(i=1, \ldots, p)$ are parameters to be estimated. The non rejection of the null hypothesis $H_{0}: a_{1}=0$ implies that $y_{t}$ is nonstationary series. In this case differences are necessary to reach stationarity.

Once the order of integration is determined, cointegration test is implemented using Johansen procedure (1988) and Johansen and Juselius technique (1990). These researchers have developed two tests to detect the number of cointegrating vectors: the maximum-likelihood test and the trace test. Once the variables are proved to be cointegrated, two different kinds of equations can be derived:

a) The long-run equation:

$$
L R G D P_{t}=\alpha_{0}+\alpha_{1} L R E X P_{t}+\alpha_{2} L R D E B T_{t}+\alpha_{3} E X C H R_{t}+u_{t}
$$

where $L R G D P, L R E X P$, and $L R D E B T$ represent the natural logarithms of real GDP, real exports, and real external debt servicing respectively. EXCHR is the exchange rate. In addition, $u_{t}$ is the stochastic error term with mean zero and a constant variance.

b) The short-run model or the vector error-correction representations:

$$
\begin{aligned}
& \Delta L R G D P_{t}=\alpha_{1}+\sum_{i=1}^{p} \theta_{1 i} \Delta L R E X P_{t-i}+\sum_{i=1}^{p} \delta_{1 i} \Delta L R D E B T_{t-i}+\sum_{i=1}^{p} \rho_{1 i} \Delta E X C H R_{t-i}+\beta_{1} E_{T C} C_{t-1}+e_{1 t} \\
& \Delta L R E X P_{t}=\alpha_{2}+\sum_{i=1}^{p} \theta_{2 i} \Delta L R E X P_{t-i}+\sum_{i=1}^{p} \delta_{2 i} \Delta L R D E B T_{t-i}+\sum_{i=1}^{p} \rho_{2 i} \Delta E X C H R_{t-i}+\beta_{2} E_{T-1}+e_{2 t} \\
& L_{R D E B T_{t}}=\alpha_{3}+\sum_{i=1}^{p} \theta_{3 i} \Delta L R E X P_{t-i}+\sum_{i=1}^{p} \delta_{3 i} \Delta L R D E B T_{t-i}+\sum_{i=1}^{p} \rho_{3 i} \Delta E X C H R_{t-i}+\beta_{3} E T C_{t-1}+e_{3 t} \\
& \operatorname{EXCHR}_{t}=\alpha_{4}+\sum_{i=1}^{p} \theta_{4 i} \Delta L R E X P_{t-i}+\sum_{i=1}^{p} \delta_{4 i} \Delta L R D E B T_{t-i}+\sum_{i=1}^{p} \rho_{4 i} \Delta E X C H R_{t-i}+\beta_{4} E T C_{t-1}+e_{4 t}
\end{aligned}
$$

where $\Delta$ represents the difference operator, $p$ is the number of lags, ETC is referred to the error terms derived from the long run relationship, and $e_{i t}(i=1,2,3,4)$ is the stochastic error term with mean zero and a constant variance.

In order to check the causal relationship between the variables we will use Granger causality test that was developed by Granger (1969). According to Granger (1988), causality tests are valid only if there exists cointegration among the involved variables. Thus a necessary precondition to causality testing is to check the cointegrationg properties of the variables of interest. We apply the standard Granger causality test on the equations (3), (4), (5), and (6).

\section{Data and Variables Description}

This study employs annual series of gross domestic product (GDP), export, exchange rate, and foreign debt servicing in Lebanon over the period 1970-2010. The data on exports and GDP are drawn from the United Nations Statistics (UNSTATISTICS) and the external debt servicing values were taken from UNICTAD for the same period. Moreover, the external debt values were taken from the Central Bank of Lebanon for the period 1979-1992 and the Ministry of finance for the period 1993-2010. The nominal figures of these variables (except the exchange rate) were deflated by the GDP deflator $(2005=100)$ in order to express them in real terms. Afterward, all variables (except exchange rate) are expressed in the natural logarithmic form of the real values.

\section{Results and Discussions}

The aim of this study is twofold. First, establish the causal relationship between exports (external debt servicing and exchange rate) and economic growth. Second, if such a relationship exists, find the direction of the causation. Annual time-series on exchange rate and the logarithms of real GDP, exports, and external debt servicing from 1970 to 2010 are employed.

In the light of the econometric methodology presented previously, the cointegration properties of the variables in question are examined. Hence, all variables in this study are tested for stationarity using Augmented 
Dickey-Fuller (ADF) and Phillips-Perron (PP) tests. The results of the unit roots tests are reported in Table (3) and indicate that all variables are nonstationary in their levels, but stationary in their first difference level at $1 \%$ level of significance. Therefore, all the variables of interest are integrated of order one I(1).

Table 3. Results of ADF and PP tests

\begin{tabular}{|c|c|c|c|c|}
\hline \multirow{2}{*}{ Variables } & \multicolumn{2}{|c|}{ Augmented Dickey-Fuller Test } & \multicolumn{2}{|c|}{ Phillips-Perron Test } \\
\hline & Level & First Difference & Level & First Difference \\
\hline$L R G D P$ & 0.3601 & $-4.1773 * * *$ & -0.6255 & $-6.1628 * * *$ \\
\hline LREXP & 0.3740 & $-3.9937 * * *$ & 0.3740 & $-3.9937 * * *$ \\
\hline LREDS & -2.1724 & $-6.3189 * * *$ & -2.4306 & $-6.3139 * * *$ \\
\hline EXCHR & -0.9647 & $-4.1304 * * *$ & -0.8309 & $-4.1304 * * *$ \\
\hline
\end{tabular}

Note: ${ }^{*}, *$, and $* * *$ show the statistical significance at the $10 \%, 5 \%$, and $1 \%$ level of significance respectively.

After stationarizing the variables, their optimal lag length is determined using Akaike's Information Criterion (AIC). The optimum lag length of the variables in questions is found to be 3 . The next step consists of testing whether these variables are cointegrated or not by applying Johansen-Juselius cointegration procedure. Two tests are used for this purpose: Trace test and Maximum Eigen Value test. The results are reported in Table (4) and show the existence one cointegrating equation for economic growth, exports, exchange rate, and external debt servicing at $1 \%$ level of significance.

Table 4. Results of cointegration tests

\begin{tabular}{|c|c|c|c|c|}
\hline \multirow[b]{2}{*}{ Null Hypothesis } & \multirow[b]{2}{*}{ Alternative Hypothesis } & \multicolumn{3}{|c|}{0.05} \\
\hline & & & Critical Value & Probability \\
\hline \multicolumn{5}{|c|}{$\lambda_{\text {trace }}$ value } \\
\hline$r=0$ & $r=0$ & 76.85043 & 47.85613 & 0.0000 \\
\hline$r \leq 1$ & $r>1$ & 26.94771 & 29.79707 & 0.1029 \\
\hline$r \leq 2$ & $r>2$ & 11.82515 & 15.49471 & 0.1655 \\
\hline$r \leq 3$ & $r>3$ & 3.416629 & 3.841466 & 0.0645 \\
\hline \multicolumn{5}{|c|}{$\lambda_{\max }$ tests } \\
\hline$r=0$ & $r=1$ & 49.90273 & 27.58434 & 0.0000 \\
\hline$r=1$ & $r=2$ & 15.12256 & 21.13162 & 0.2804 \\
\hline$r=2$ & $r=3$ & 8.408522 & 14.26460 & 0.3387 \\
\hline$r=3$ & $r=4$ & 3.416629 & 3.841466 & 0.0645 \\
\hline
\end{tabular}

Notes: Trace and max-eigenvalue tests indicate 1 cointegrating equation at the 0.01 level of significance. $r$ indicates the number of cointegrating vector and $\lambda_{\text {trace }}$ and $\lambda_{\max }$ are tests statistic of trace and maximum eigenvalue tests respectively.

These results imply that a long-run association exists among the exchange rate and the logarithms of real GDP, real exports, and real external debt servicing. Then, the long-run estimated coefficients are reported in table (5).

The statistically significant positive long-run coefficient of $L R E X P$ indicates that exports have positive effects on economic growth. Furthermore, exchange rate $(E X C H R)$ has a statistically positive coefficient that reveals a positive effect on economic growth. However, the long-run coefficient of LREDS is insignificant even at $10 \%$ significance level. Therefore, we conclude that foreign debt servicing has no effect on economic growth in the long-run.

Table 5. Estimated long-run model

\begin{tabular}{lccc}
\hline Dependent Variable $L R G D P$ & & & \\
\hline Variable & Coefficient & Standard Error & $30.3517^{* * *}$ \\
\hline Constant & 8.42206 & 0.2791 & $3.4580^{* * *}$ \\
LREXP & 0.1505 & 0.0435 & -0.8928 \\
LREDS & 0.0188 & 0.0210 & $2.5245^{* *}$ \\
EXCHR & $9.45 \mathrm{E}-05$ & $3.7 \mathrm{E}-05$ & 0 \\
\hline
\end{tabular}

Note: *, **, and $* * *$ indicate the rejection of the null hypothesis at the $10 \%, 5 \%$, and $1 \%$ level of significance respectively. 
Since there exists one cointegrating vector in the four variables involved in the cointegrating tests, it is convenient to perform multivariate Granger causality tests based on vector error correction models (VECM). These latter include an error correction term (ETC) that captures the short-run dynamics. The results of these tests from VECM specification, $\chi^{2}$-statistics, probability (in parentheses), and the error correction term (ETC) coefficient from each four equations are reported in table (6).

Table 6. Results of Granger causality tests built on VECM

\begin{tabular}{|c|c|c|c|c|c|}
\hline \multirow{2}{*}{ Dependent Variable } & \multicolumn{5}{|c|}{ Short-run lagged differences } \\
\hline & $\triangle L R G D P$ & $\triangle L R E X P$ & $\triangle L R E D S$ & $\triangle E X C H R$ & $E T C_{t-1}$ \\
\hline$\triangle L R G D P$ & - & $\begin{array}{c}28.21426 * * * \\
(0.000)\end{array}$ & $\begin{array}{c}8.584848 * * \\
(0.0354)\end{array}$ & $\begin{array}{c}9.43783 * * \\
(0.0240)\end{array}$ & $\begin{array}{c}-0.82582 * * * \\
(-3.12986)\end{array}$ \\
\hline$\triangle L R E X P$ & $\begin{array}{l}2.24016 \\
(0.5241)\end{array}$ & - & $\begin{array}{l}1.308360 \\
(0.7271)\end{array}$ & $\begin{array}{l}0.861229 \\
(0.8348)\end{array}$ & $\begin{array}{c}0.58869 \\
(0.85566)\end{array}$ \\
\hline$\triangle L R E D S$ & $\begin{array}{c}34.52563^{* * *} \\
(0.0000)\end{array}$ & $\begin{array}{c}6.442964 * \\
(0.0919)\end{array}$ & - & $\begin{array}{c}15.50800^{* * * *} \\
(0.0014)\end{array}$ & $\begin{array}{c}-2.71223 * * * \\
(-5.69149)\end{array}$ \\
\hline$\triangle E X C H R$ & $\begin{array}{l}4.308169 \\
(0.2301)\end{array}$ & $\begin{array}{c}2.026306 \\
(0.5670)\end{array}$ & $\begin{array}{l}1.594139 \\
(0.6607)\end{array}$ & - & $\begin{array}{l}-147.9639 \\
(-0.63633)\end{array}$ \\
\hline
\end{tabular}

Notes: values presented in the last column are the $E C T$ estimated coefficients and values in parenthesis the t-values. All other values are the asymptotic Granger $\chi 2$-statistics. *, **, and *** indicate the statistical significance at the $10 \%, 5 \%$, and $1 \%$ level of significance respectively and values in parentheses are the $p$-values.

Our results indicate the validity of export-led growth hypothesis in the long run. Exports are considered as engine for the process of growth since they engender scare foreign exchange reserves that are required to finance imports of goods such as energy and investment goods. These latter are essential for the formation of capital and economic growth. Exports diminish the weight on the balance of payments and engender employment opportunities (Eita and Jordaan, 2007). Moreover, exports can lower the effect of external shocks on the domestic economy. The essential role for exports as a key to economic growth was also stressed by Senhadji and Montenegro (1999). Barro (1991, 1997) and Gemmell (1996) argued also that exports are an important determinant of economic growth. They assumed that a higher level of exports enhances productivity, which results in an increase in production of high value added goods. This situation leads in return to an overall improvement in economic growth.

The results of Granger causality tests show that a bidirectional causality between external debt servicing and GDP exists at $1 \%$ level of significance and there is a unidirectional Granger causality going from $i$ ) export to GDP at 5\% level of significance, ii) exchange rate to GDP at 5\% level of significance, iii) export to external debt servicing at $10 \%$ level of significance, and $i v$ ) exchange rate to external debt servicing at $5 \%$ level of significance. Moreover, the statistically significant $E C T$ coefficients at $1 \%$ for GDP and external debt servicing indicate that these obtained causalities are also accompanied with short run dynamics. On the other hand, ECT coefficients for exchange rate and exports are insignificant with the absence of any causal effect. As a result, the findings imply that both exports and exchange rate matter in the economic growth in the short-run in Lebanon. Moreover, exports have also an impact on external debt servicing in the short-run.

Based on the achieved results, we notice that if a large proportion of the export earnings is being employed to service foreign debt than we would expect a positive relationship between export revenue growth and debt servicing. This is because countries with promising export potential are likely to obtain more foreign loans and, therefore, to bear larger external debt and, consequently, a larger foreign debt servicing burden [Feder (1982)]. Since the resources from exports could be directed to foreign debt servicing instead of being used in the investment, the relationship between exports and economic growth may not be significant in the short run.

It is surprising that there is not any causality between export and exchange rate. This can be referred to the fact that exchange rate has been stabilized for a long time by adopting the policy of fixed exchange rate since 1992 . 


\section{Conclusion}

This study analyses empirically the causal relations among economic growth, export, exchange rate, and foreign debt servicing in Lebanon, over a period of 40 years from 1970 to 2010.

Public debt has become an increasingly serious problem for Lebanon due mainly to its crowding out public finances because of the huge debt-service charges. In 2010 the total debt was $\$ 52.6$ billion, of which $39.1 \%$ is attributed to external debt. According to the World Bank, when the external debt of a country reaches to $80 \%$ of its GNP, it becomes unsustainable. Although the external debt of Lebanon did not become unbearable in the period of analysis, we can say that the country does not feel at ease when it external debt equals or exceeds $53.5 \%$ of its GNP.

Furthermore, the ratio of exports to gross domestic product (GDP) experienced ups and downs over the period from 1970 to 2010 . The ratio was $37.38 \%$ in 1979 , arrived to its lowest level $8.56 \%$ in 1993 , and then increased to reach $21.42 \%$ in 2010 . These fluctuations are due to internal and external political events.

In order to clarify whether exports, exchange rate, and external debt servicing cause economic growth or vice versa, a vector autoregressive model is developed. Moreover, Granger causality technique is used to assess the direction of causation.

The results showed bidirectional causality between economic growth and external debt servicing, unidirectional causality running from exports to economic growth, unidirectional Granger causality running from exports to external debt, and unidirectional causality flowing from exchange rate to economic growth. The presence of a causal link between exports and growth has implications of great consequence on development strategies for developing countries. If export causes economic growth, then the achievement of a certain degree of development may be a prerequisite for the country to expand its exports. Our findings provide evidence to support the export-led growth hypothesis. Thus, exports are important in fueling economic growth.

\section{Acknowledgement}

The author would like to gratefully acknowledge the financial support provided by National Council for Scientific Research, (CNRS) Lebanon.

\section{References}

Afzal, M. (2006). Causality between exports, world income and economic growth in Pakistan. International Economic Journal, 20(1), 63-77. http://dx.doi.org/10.1080/10168730500515399

Ahmed, Q., Butt, M., Sabihuddin, M., \& Shaista, A. (2000). Economic growth, export and external debt causality: The case of Asian countries. The Pakistan Development Review, 34(4), 591-608.

Amoateng, K., \& Amoako-Adu, B. (1996). Economic growth, export and external debt causality: the case of African countries. Applied Economics, 28, 21-27. http://dx.doi.org/10.1080/00036849600000003

Awokuse, T. O. (2005). Exports, economic growth and causality in Korea. Applied Economics Letters, 12(11), 693-96. http://dx.doi.org/10.1080/13504850500188265

Awokuse, T. O. (2007). Causality between exports, imports, and economic growth: Evidence from transition economies. Economics Letters, 94, 389-395. http://dx.doi.org/10.1016/j.econlet.2006.08.025

Baharumshah, A. Z., \& Rashid, S. (1999). Exports, imports and economic growth in Malaysia: Empirical evidence based on multivariate time series. Asian Economic Journal, 13(4), 389-406.

Barro, R. J. (1991). Economic growth in cross-section of countries. Quarterly Journal of Economics, 106, 407-443.

Barro, R. J. (1997). Determinants of economic growth: A cross-country empirical study. The MIT Press: Cambridge Massachusetts, the United States.

Cetintas, H., \& Barisik, S. (2009). Export, import and economic growth: The case of transition economies. Transit Stud Rev, 15, 636-649. http://dx.doi.org/10.1007/s11300-008-0043-0

Demirhan, E., \& Akcay, S. (2005). The causality relationship between export growth and economic growth: Empirical evidence from selected MENA countries. Iktisat Isletmeve Finans, 20(230), 124-31.

Dickey, D., \& Fuller, W. (1981). Likelihood ratio statistics for autoregressive time series with a unit root. Econometrica, 49, 1057-1072. http://dx.doi.org/10.2307/1912517 
Din, M. (2004). Exports, imports, and economic growth in South Asia: Evidence using a multivariate time-series framework. Pakistan Development Review, 43(2), 105-24.

Eita, J. H., \& Jordaan, A. C. (2007). South Africa exports of metals and articles of base metal: A gravity model approach. Journal for Studies in Economics and Econometrics, 31(3), 81-95.

Gemmell, N. (1996). Evaluating the impacts of exports stocks and accumulation on economic growth: Some new evidence. Oxford Bulletin of Economics and Statistics, 58, 9-28.

Granger, C. W. J., \& Newbold, P. (1974). Spurious regression in econometrics. Journal of Econometrics, 2, 111-120. http://dx.doi.org/10.1016/0304-4076(74)90034-7

Granger, C. W. J. (1969). Investigating causal relations by econometric and cross- spectral method. Econometrica, 37(3), 424-438. http://dx.doi.org/10.2307/1912791

Hatemi J. A. (2002). Export performance and economic growth nexus in Japan: A bootstrap approach. Japan and the World Economy, 14(1), 25-33. http://dx.doi.org/10.1016/S0922-1425(01)00071-8

Hsiao, M. C. W. (1987). Testing causality and exogeneity between exports and economic growth: The case of the Asian NICs. Journal of Economic Development, 12, 143-159.

Johansen, S. (1988). Statistical analysis of cointegration vectors. Journal of Economic Dynamics and Control, 12, 231-254. http://dx.doi.org/10.1016/0165-1889(88)90041-3

Johansen, S., \& Juselius, K. (1990). Maximum likelihood estimation and inference on cointegration with application to the demand for money. Oxford Bulletin of Economic and Statistics, 52, 169-210. http://dx.doi.org/10.1111/j.1468-0084.1990.mp52002003.x

Jones, J. D. (1989). A comparison of lag-length selection techniques in tests of Granger causality between money growth and inflation: Evidence for the US. 1959-86. Applied Economics, 21, 809-22. http://dx.doi.org/10.1080/758520275

Khalid, A. M., \& Cheng, B. T. (1997). Imports, exports and economic growth: Cointegration and causality tests for Singapore. Singapore Economic Review, 42(2), 32-39

Lee, D. Y., \& Pan, M. S. (2000). On exports and economic growth in East Asian countries: Linear and nonlinear causality analyses. Pennsylvania Economic Review Fall, 9(2), 66-78.

Mah, J. S. (2005). Export expansion, economic growth and causality in China. Applied Economics Letters, 12(2), 105-07. http://dx.doi.org/10.1080/1350485042000314343

Phillips, P. C. B., \& Perron, P. (1988). Testing for a unit root in time series regression. Biometrika, 75, 335-46. http://dx.doi.org/10.2307/2336182

Ribeiro, R., \& Francisco F. (2001). Exports, imports, and economic growth in Portugal: evidence from causality and cointegration analysis. Economic Modeling, 18(4), 613-23.

Senhadji, A. S., \& Montenegro, C E. (1999). Time series analysis of export demand equations: A cross- country analysis. IMF Staff Papers, 46(3), 259-273.

Sheehey, E. J. (1990). Exports and growth: a flawed framework. Journal of Development Economics, 27, 111-16. http://dx.doi.org/10.1080/00220389008422186

Shirazi, N. S., \& Manap, T. A. A. (2004). Exports and economic growth nexus: The case of Pakistan. Pakistan Development Review, winter, 43(4), 563-79.

Tang, C. F., \& Lai, Y. W. (2011). The stability of export-led growth hypothesis: Evidence from Asia's Four Little Dragons. MPRA Paper, No. 27962.

Notes

Note 1. "Financial crises in East Asia". www.worldscibooks.com. 